原著論文

\title{
ハイドロキシアパタイト顆粒を用いた下顎無歯顎 顎堤形成法に関する補経学的検討
}

第 1 報 顎堤形態の分析と評価

\author{
田中 收 平井 敏博 村瀬 博文*
Prosthodontic Analysis in Mandibular Ridge Augmentation with Hydroxyapatite Particle

\section{Part I. Evaluation of Alveolar Ridge Form}

\author{
Osamu Tanaka, Toshihiro Hirai and Hirofumi Murase*
}

\begin{abstract}
Ten patients received augmentation of the deficient mandibular alveolar ridges using particulate hydroxyapatite (HAP). Investigations were undertaken to evaluate the augmented ridge form during a postoperative period from 6 to 30 months. No serious troubles attributable to the use of the implant and the surgical procedures were observed. The mandibular complete dentures constructed on postaugmented ridges were clinically judged to be more successfull with the use of the surgical stent. Measurement of vertical ridge heights with panoramic radiographs showed that the augmented portions of the alveolar ridges were on the average of $59 \%$ higher than their preoperative heights. Over a period of 30 months, beginning 1 month after augmentation, longitudinal reduction of ridge heights was approximately $6 \%$. An average enlargement of $32 \%$ was observed in measurements of the denture-bearing area. The contour of the augmented alveolar ridges showed an increase of height at the lingual area and of breadth at the buccal area, which may provide increased retention and stability for complete dentures. The placement and ligation of the surgical stent proved beneficial to the HAP augmentation.

From these findings, the HAP augmentation appears to be effective in improving the ridge form and denture success, provided that consideration is given to prosthodontics and the surgical stent is used.
\end{abstract}

\footnotetext{
東日本学園大学歯学部歯科補緅学第 1 講座（主任 : 平并敏博 教授)

* 東日本学園大学歯学部口腔外科第 2 諈座（主任 : 村瀬博文教 授)

The 1 st Department of Prosthetic Dentistry, Faculty of

Prof. Toshihiro Hirai)

* The 2 nd Department of Oral Surgery, Faculty of Dentistry, Higashi-Nippon-Gakuen University (Chief : Prof. Hirofumi Murase) 昭和 63 年 6 月 27 日受付
} Dentistry, Higashi-Nippon-Gakuen University (Chief : 
Key words : alveolar ridge augmentation, denture bearing area, edentulous patient, hydroxyapatite, ridge form

\section{I. 緒言}

無歯顎補緅における咀嚼機能の回復には，義歯の支持 基盤である顎堤の形態が大きく関与しているが，たとえ その吸収が高度な症例であっても, 補緅学の基本的学理 にのっとった適切な義歯により，患者の咬合機能の回復 は十分可能である.しかし，もし䪽堤を良好な形態に回 復することが可能であるならば，義歯による患者の機能 回復はさらに向上しうると考えられる. そのために，従 前より外科的な顎堤形態の改善，すなわち頡堤（歯槽堤） 形成法が種々試みられてきたが1 9)，外科的侵襲の程度， 移植骨の生着率, 術後の骨吸収 ${ }^{8,9)}$ などの問題が残り, 必 ずしも満足すべき臨床効果が得られず，一般的な処置法 として広く普及するには至らなかった。

しかし，近年，骨欠損の補填材として注目されている 合成ハイドロキシアパタイト (Hydroxyapatite) $\left(\mathrm{Ca}_{10}\right.$ $\left.\left(\mathrm{PO}_{4}\right)_{6}(\mathrm{OH})_{2}\right)$ (以下, 本文中では HAP と略す) の顆粒, あるいはブロックを頡堤の骨膜下に埋入する顎堤形成法 が可能となり，優れた臨床成績が報告されている10 57). 特に, 顆粒状 HAP を使用する方法は, 1980 年, Kent $ら^{10,11)}$ により発表されて以来, 外科的術式が簡便で侵襲 も少なく, 安全性が高く, 術後の顎堤の変化も少ないな ど，その有用性を報告する論文が多い. しかし，それら 論文の多くは手術術式を中心とした口腔外科学的立場か らのものであり, 補緅学的立場から本法に詳細な検討を 加えた論文は少なく，義歯の支持基盤として形成された 顎堤の評価も必ずしも十分ではないと思われる.

著者らは, 顆粒状 HAP を下顎顎堤に埋入した症例に
関して, 術前術後の萼堤形態, 䫟堤粘膜の感覚闒, 義歯 の機能などに関して分析検討を加えているが，今回は， その術式および䪽堤形態について検討した結果を報告す る.

\section{II. 顎堤形成法}

診断から外科手術，それに続く補緅処置は表 1 に示す スケジュールに従った.

\section{1. 対象者}

対象者は，咀嚼障害を主訴とし，義歯の製作を希望し て本学補緅科を受診した 43〜83 歳までの上下頡無歯䪽 患者 9 名と, 上䫑76321|167 欠損, 下顎無歯顎の 1 名（症例 4 ）の計 10 名である（表 2 ). これらは下顎 顎堤の吸収が著しく，顎堤形態を改善することによりさ

表 1 顎堤形成法のスケジュール

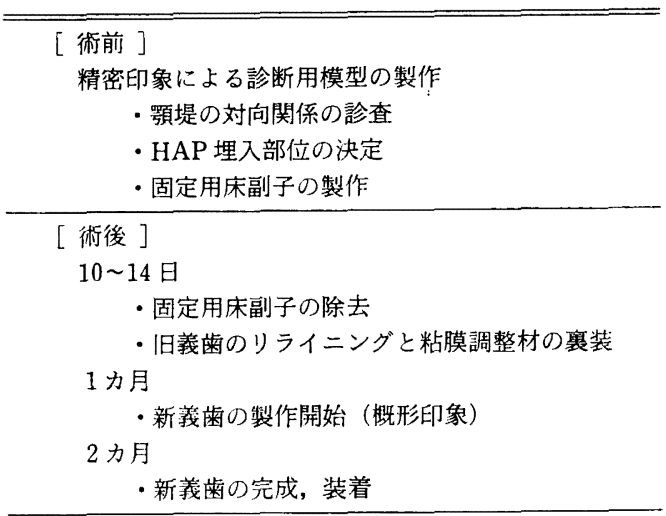

表 2 対 象 者

\begin{tabular}{|c|c|c|c|c|c|}
\hline 患者 & 性 & 年齢 & 顎堤形成部位 & 床副子 & 術後観察期間 \\
\hline 1 & M & 69 & 下頡臼歯部 & 固定用 & 30力月 \\
\hline 2 & $\mathrm{~F}$ & .67 & 下顎臼歯部 & 固定用 & 18力月 \\
\hline 3 & $\mathrm{~F}$ & 56 & 下頡前歯部, 臼歯部 & 固定用 & 18力月 \\
\hline 4 & M & 63 & 下顎臼歯部 & 固定用 & 12力月 \\
\hline 5 & M & 68 & 下顎前菌部, 臼歯部 & 固定用 & 6力月 \\
\hline 6 & $\mathrm{~F}$ & 68 & 下嚬前歯部, 兒歯部 & 固定用 & 6力月 \\
\hline 7 & $\mathrm{~F}$ & 73 & 下顎前歯部, 白歯部 & ガイド固定兼用 & 30力月 \\
\hline 8 & $\mathrm{~F}$ & 43 & 下顎前曾部, 臼歯部 & 使用せず & 24 力月 \\
\hline 9 & $\mathrm{~F}$ & 83 & 下顥臼歯部 & 使用せず & 12力月 \\
\hline 10 & $\mathrm{~F}$ & 71 & 下顎臼歯部 & 使用せず & 6力月 \\
\hline
\end{tabular}




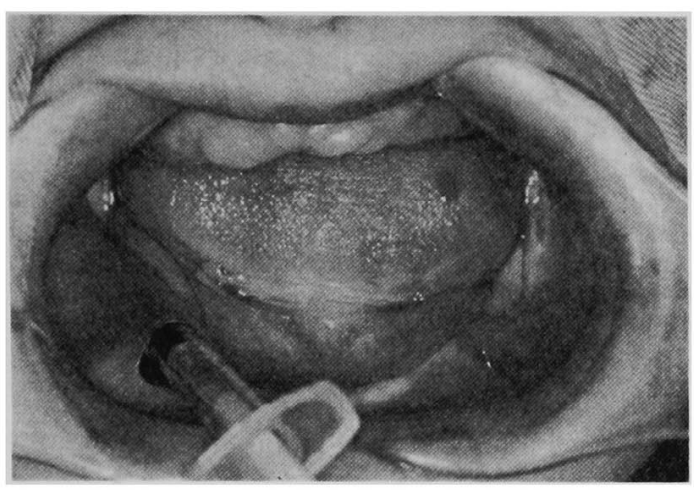

図 1 骨膜下トンネル内への HAP 顆粒の注入

らに良好な義歯の作製が可能と診断され，本人からの希 望があった症例である．また，いずれも特記すべき疾患 はなく，全身状態も良好であった.

\section{2. 使用材料}

使用した顆粒状 HAP は, $\mathrm{Ca} / \mathrm{P}$ モル比 1.67 で, 湿式 法にて $900^{\circ} \mathrm{C}$ で焼成された粒径約 500〜900 $\mu \mathrm{m}$ のもの (太平化学産業) とアパセラム $\mathrm{G}$ (旭光学) である. 前者

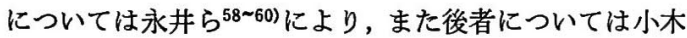

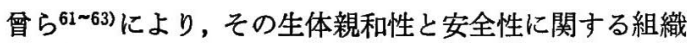
病理学的な検討結果が報告されている.

\section{3. 外科手術}

1）埋入部位の診断と固定用床副子の製作

まず，顆粒状 HAP の埋入によって形成されるべき䪽 堤形態を決定するために，精密印象と咬合採得の後，診 断用模型を咬合器に装着し，パラフィンワックスにて枵 堤の希望形態を形成した.つぎに，これを印象して得ら れた予測模型の顎堤上に厚さ $2.5 \mathrm{~mm}$ の透明フィルムを Erkopress により圧接し，固定用の床副子（症例 1 6) またはガイド・固定兼用床副子（症例 7 ）を作製した. なお, 症例 8〜10は床副子を使用しなかった（表 2).

2) HAP 顆粒の埋入

HAP 顆粒の下顎骨骨膜下への埋入手術は本学口腔外 科にて行った．術式の概要は以下の通りである. まず埋 入部位の顎堤粘膜を浸潤麻酔し，片側の犬歯相当部に, 口腔前庭部から歯槽頂を越えて縦切開を加えた. この切 開部より，臼後パッド前縁部まで歯槽頂部の骨膜を後方 へとトンネル状に骨面から剝離した. 次に, 症例 1〜8 では, HAP 顆粒を骨膜と骨の間に形成されたトンネル内 にシリンジにて注入した (図 1). 一方，症例 9，10では シリンジを使用せず，顆粒を鋭匙にて搬入した．注入ま

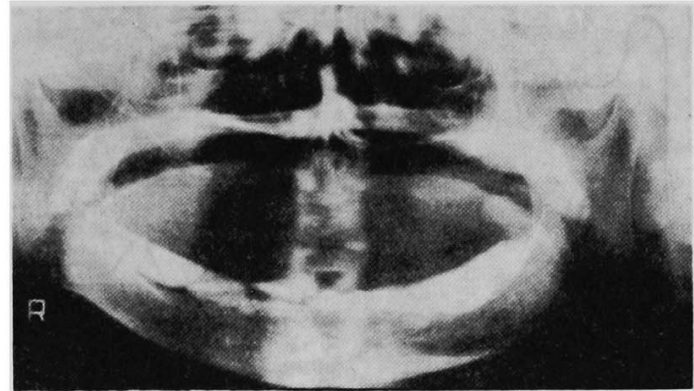

図 2 術後のパノラマX線写真の一例（症例 5 )

たは搬入後, 粘膜上より術者の手指で領堤形態を成形, 圧接して整えた。

なお, 症例 7 では埋入に先立ちガイド・固定兼用床副 子をあらかじめ挿入しておき，注入路を確保してからそ の下部にシリンジにて HAP を注入した.

注入後は創面を緊密に縫合した。

3） HAP の固定

症例 1〜6では予測模型上であらかじめ作製しておい た固定用床副子を下顎骨に囲繞結华して, HAP 顆粒の固 定を図った. 症例 7 では, HAP 注入前に挿入したガイ ド ·固定兼用床副子をそのまま残し，䫟堤の固定を図っ た. 症例 8〜10 では, 術後の固定は行わなかった.

床副子は術後約 7〜10日で除去した.

図 2 は術後の顥堤のパノラマX線写真の一例 (症例 5) である。

4) 外科手術後の偶発症

外科手術後, 24 時間以内の術後疼痛が 10 例中 7 例に 認められた. 特に床副子使用例に著明であったが, 鎮痛 剂の投与によって軽減した．局所の炎症症状は軽度であ りほぼ 3 日以内に消失した. 床副子除去時に床副子の圧 迫による裖瘡性潰瘍が 3 例に認められたが, 床の除去後 数日で消失した. また，縫合創の哆開が 2 例に，縫合創 からの HAP 顆粒の漏出が 3 例に認められたが，いずれ も20日以内には消失した. オトガイ神経領域の軽度の 麻瘏が 1 例に認められたが, 約 2 力月で正常に復帰し た. その他, 重篤な術後の偶発症は認められず, 外科的 に極めて良好な経過をたどった.

\section{4. 補綴処置}

1）旧義歯のリライニングと粘膜調整材の裏装

外科手術後, 7〜10 日で固定用床副子を除 去 後, 旧義 歯にリライニングを行い，粘膜調整材にて裹装した. こ れを暫間義歯として使用させた。 
$146-1348$

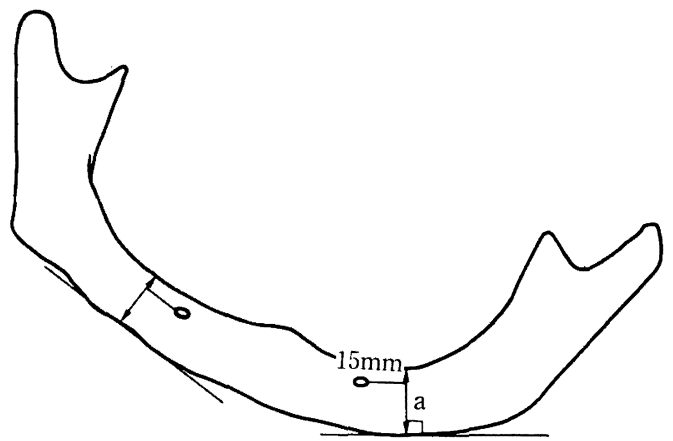

図 3 パノラマX線写真による下箩骨体の高さの計測部位(a)

2）新義歯の製作

外科手術約 1 力月後より新義歯の製作を通法により開 始した.

新義歯装着の時期は，平均的には顎堤形成術後約 2 力 月であった．装着後の調整も通常と同様であるが，調整 完了後も定期的な経過観察を行った.

\section{III. 䫑堤形態の分析方法}

\section{1. パノラマX線写真による計測}

術前，術直後䇽よび $0.5,1,3,6,12,18,24,30$ 力月 後にX線パノラマ撮影を行い, Kent らの方法 ${ }^{11,12)}$ に従 い, オトガイ孔後方 $15 \mathrm{~mm}$ における下䪽骨体の高さを 下顎骨下縁の接線に対して垂直にノギスで計測した（図 3). なお, 正中部付近では, パノラマX線写真の鮮映度 が良好でなかったため, 前歯部の計測は行わなかった。

\section{2. 義歯負担域面積の計測}

全部床義歯臨床経験 10 年以上の同一術者が同一術式 にて精密印象を採得し, 得られた術前・術後の顎堤模型 の面積を, 䫟堤頂で煩舌的に 2 分して計測, 比較した. なお, 術後の顎堤には術前の䫟堤頂と思われる索状の組 織が残存しており，ここを買堤頂とした。

計測は，個人トレーとシリコン印象材を用いて顎堤模 型を印象し, 得られた印象材の薄膜をデジタイザー (OSCON 社製 OSCON SQ-3100) 上でトレースし，パー ソナルコンピュータ（日本電気社製 PC-9801）にて行っ た.

\section{3. 顎堤断面形態の比較}

㴿堤断面形態の比較は，前項と同様にして得られた模 型を切断することにより行った. 切断部位は臼後パッド 前縁と正中部，およびその両者間を 4 等分した部位の計
32 巻 6 号 (1988)

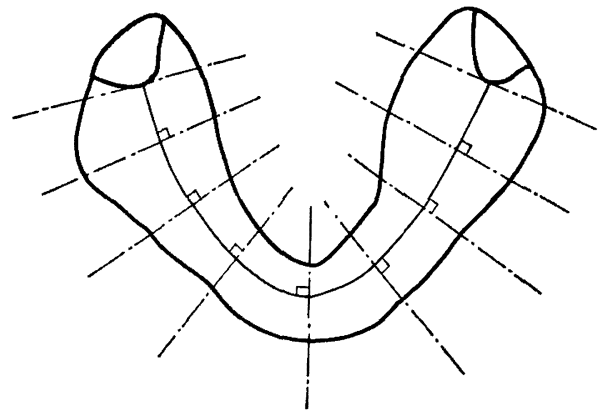

図 4 頻堤の切断部位

9 力所とし(図 4)，仮想咬合平面に垂直に切断した.得ら れた断面図を口腔底の高さで重ね合せ，トレースした。

\section{IV. 分析結果}

\section{1. パノラマ X線写真による計測}

術前・後の下顥骨体の高さ，およびその経時的変化を 図 5 に示した. また, 術直後および術後 1 力月を基準と した高さの変化を表 3 に示した. 䫛堤形成術後の下䫑骨 体の高さは，術前に比べていずれの症例においても著明 に増加しており，最大で $92 \%$ (症例 9), 全症例の平均で 約 59\%の増加が認められた.

経時的な高さの減少に関しては，術直後を基準として 算出すると, 術後 6 力月での平均は約 $7 \%$ であり, 12 力 月後で約 $8 \%, 24$ 力月後で約 $9 \%, 30$ 力月後では約 $10 \%$ （症例 1,7のみ）であった. また，この減少率を，義歯 製作開始時期となる手術後 1 力月目を基準として計算す ると, 術後 6 力月では平均約 $3 \%, 12$ 力月後で約 4\%, 24 力月後で $5 \%, 30$ 力月後では約 $6 \%$ であった.

また，床副子の使用症例（症例 1〜7）では，非使用症 例（症例 8〜10）に比べて顎堤の経時的変化が少なかっ た.

\section{2. 義菌負担域面積}

術後の䫟堤における義歯負担 (支持) 域面積は術前に 比べ著しく増加しており, 最大で約 $40 \%$ (症例 2), 全 10 症例平均では約 $32 \%$ の増加が認められた（図 6-a,b, 表 4). 煩舌側別に增加率をみると，煩側が平均 $27 \%$, 舌側が $39 \%$ であり，ほとんどの症例において舌側の方 が著明であり，次項の頷堤断面形態からも明らかなよう に，顎堤の高さの増加が大きいことを示していた. ただ し, 症例 7, 8 においては煩側の増加率の方が大きく, 高さよりも煩側への広がりを示していた，なお，床副子 


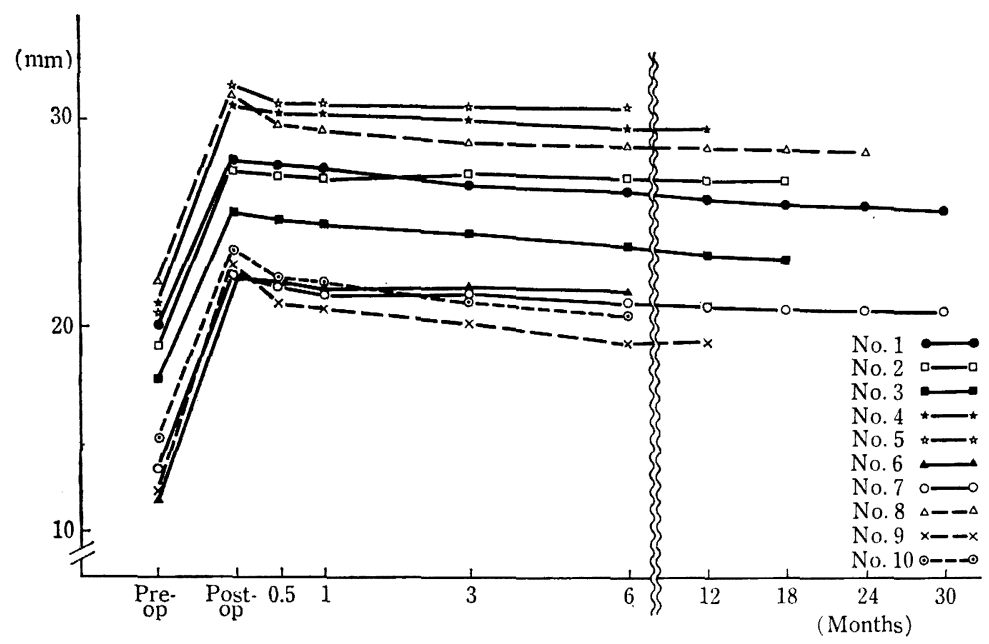

図 5 下影骨体部の高さの経時的変化

表 3 術直後および術後 1 カ月を基準とした下䫓骨体部の高さの経時的変化

\begin{tabular}{|c|c|c|c|c|c|c|c|c|c|c|}
\hline \multirow[b]{2}{*}{ 症 例 } & \multirow[b]{2}{*}{ 術後増加率 } & \multicolumn{5}{|c|}{ 術直後を基準とした骨体部の高さの変化 } & \multicolumn{4}{|c|}{ 術後 1 力月を基準とした変化 } \\
\hline & & $1 \mathrm{M}$ 後 & $6 \mathrm{M}$ 後 & $12 \mathrm{M}$ 後 & $24 \mathrm{M}$ 後 & $30 \mathrm{M}$ 後 & $6 \mathrm{M}$ 後 & $12 \mathrm{M}$ 後 & $24 \mathrm{M}$ 後 & $30 \mathrm{M}$ 後 \\
\hline 1 & 1.366 & 0.973 & 0.955 & 0.929 & 0.920 & 0.911 & 0.982 & 0.954 & 0.945 & 0.936 \\
\hline 2 & 1.461 & 0.991 & 0.973 & 0.964 & & & 0.982 & 0.973 & & \\
\hline 3 & 1.457 & 0.961 & 0.941 & 0.922 & & & 0.980 & 0.959 & & \\
\hline 4 & 1.464 & 0.984 & 0.959 & 0.951 & & & 0.975 & 0.967 & & \\
\hline 5 & 1.506 & 0.976 & 0.968 & & & & 0.992 & & & \\
\hline 6 & 1.875 & 0.967 & 0.944 & & & & 0.977 & & & \\
\hline 7 & 1.800 & 0.956 & 0.933 & 0.922 & 0.900 & 0.900 & 0.977 & 0.965 & 0.942 & 0.942 \\
\hline 8 & 1.378 & 0.944 & 0.919 & 0.919 & 0.911 & & 0.974 & 0.974 & 0.966 & \\
\hline 9 & 1.917 & 0.913 & 0.859 & 0.859 & & & 0.940 & 0.940 & & \\
\hline 10 & 1.638 & 0.926 & 0.874 & & & & 0.943 & & & \\
\hline 全症例平均値 & 1.586 & 0.959 & 0.933 & 0.924 & 0.910 & 0.905 & 0.972 & 0.962 & 0.951 & 0.939 \\
\hline (症例 $1 \sim 6$ ) & 1.521 & 0.975 & 0.957 & 0.941 & & & 0.981 & 0.963 & & \\
\hline （症例 $9 ， 10$ ) & 1.777 & 0.920 & 0.866 & 0.859 & & & 0.942 & 0.940 & & \\
\hline
\end{tabular}

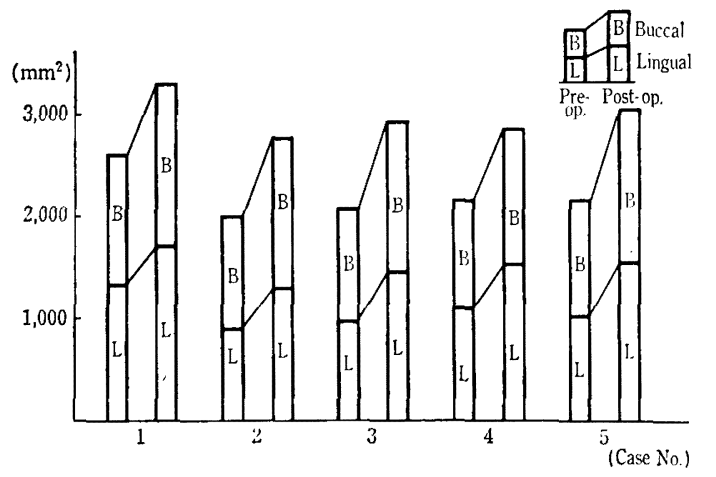

図 6-a 術前・後の義歯負担城面積の比較（症例 1 5）

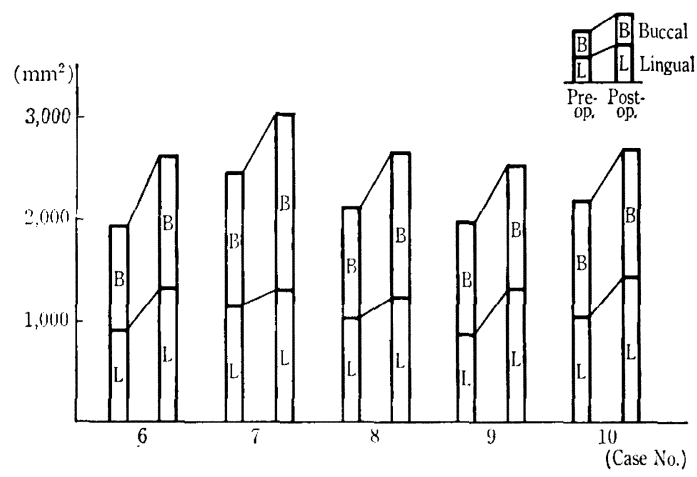

図 6-b 術前・後の義歯負担域面積の比較（症例 6 10） 
表 4 術後の義歯負担域面稍の増加率

\begin{tabular}{c|ccc}
\hline \hline \multirow{2}{*}{ No. } & \multicolumn{3}{|c}{ 增 加 率 } \\
\cline { 2 - 4 } & LINGUAL & BUCCAL & TOTAL \\
\hline 1 & 1.389 & 1.201 & 1.292 \\
2 & 1.548 & 1.287 & 1.397 \\
3 & 1.485 & 1.305 & 1.386 \\
4 & 1.366 & 1.216 & 1.291 \\
5 & 1.515 & 1.277 & 1.387 \\
6 & 1.424 & 1.307 & 1.363 \\
7 & 1.129 & 1.359 & 1.251 \\
8 & 1.192 & 1.324 & 1.259 \\
9 & 1.483 & 1.119 & 1.283 \\
10 & $1.32 \times$ & 1.133 & 1.242 \\
\hline 全症例平均値 & 1.392 & 1.266 & 1.323 \\
症例 $1 \sim 6$ & 1.454 & 1.266 & 1.353 \\
症例 $8 \sim 10$ & 1.345 & 1.192 & 1.261 \\
\hline
\end{tabular}

使用症例では非使用症例に比べて面積の増加率が大きか った.

\section{3. 顎堤断面形態}

図 7 は, 全 10 症例それぞれの術前・後の顥堤形態を トレースし，重权合せたものである．いずれの症例にお いても，舌側部は垂直面が増加してより高く形成されて いた. 煩側では口腔前庭も同時に挙上され, 必ずしも十 分な高さが獲得されていたわけではないが, 術後に床副 子を使用した症例 1 6 6おいては, 口腔前庭が広く拡 張されて平坦化し, 大臼歯部では広い煩棚が獲得されて いた.

前歯部では高さの改善はほとんど認められなかった が, 口腔前庭の拉張が認められ，唇側に抗大していた.

\section{V. 考察}

\section{HAP 顆粒と組織学的反応についての文献的考察}

生体の硬組織の構成主成分であるハイドロキシアパタ イト（HAP）が生体親和性に優れており，生体補填材料 として安全で有効であることは，多くの病理組織学的報 告㧍よび臨床症例報告により確認されている ${ }^{58 ~ 74)}$. その 応用は人工歯根63,71,75 77) や, 種々の原因による骨欠損, たとえば辢胞, 腫湯, 歯周炎, 口蓋裂などの骨補填材と して多岐にわたっておりり 20 22,36,68)，良好な結果が報告さ れている.

今回, 著者らが使用した HAP 顆粒についても, 永井 $ら^{58 \sim 60)}$, 小木曾 ${ }^{61 \sim 63)}$ の研究により，顎骨骨髄欠損部また
32 巻 6 号 (1988)

は抜歯窩に填入された場合，その周囲に新生骨が添加さ れ完全に骨に埋入されることが確められている.

しかし，本法のように，顆粒状 HAP が骨膜下に埋入 された場合に組織学的にどのような経過をたどるかにつ

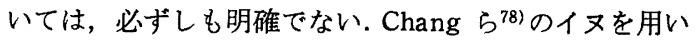
た実験によれば，埋入 1 力月後には顆粒間隙にまだ空隙 が認められるものの柾性結合織が観察され，3 カ月後に は多量の疎性結合織で満たされて, 骨面上に新生骨の形 成が認められる. 6 カ月後には底部のインプラント界面 にはさらに新生骨の形成がみられ，9力月後にはハーバ 一ズ管を有する新生骨の形成がさらに進行して HAP の 間隙を満たすようになる。 また, 魚島ら ${ }^{79}$, 益田ら ${ }^{80)}$ も 又を用いた実験で 4 力月後に骨の形成を認めており， Frame $5^{81)}$ も 6 力月後に骨形成を認め, その速度は緻密 体よりも多孔体の方が速かったと報告している.さらに， Block ら ${ }^{82,83)}$ は, 同じくイヌを用いて, HAP のみの埋入 では 52 週後もほとんど骨の形成は認められなかったが, 自家骨または脱灰骨を混入すると $12 \sim 26$ 週で HAP 顆 粒間に骨の新生が認められたことを報告している.

これらの動物実験の結果に対し，実際に顥堤形成を行 った患者の組織を観察した報告もみられる. Beirne $5^{84)}$ は, 影堤形成術後 12 力月においても HAP 粒子塊 全体が骨で満たされることはなく, HAP 粒子間は結合織 で満たされ骨面に線維性付着をして，骨形成は認められ なかったと報告している. また, Donath ら ${ }^{85)}$ は 12 力月 後に骨面付近にのみ骨の新生を認めている。一方, Page ${ }^{86)}$ は, 術後 10 力月の組織を観察し顆粒間に新生骨 の形成を認めており, Chao ${ }^{87)}$ も症例で術後 5 力月あ るいは 12 力月で顆粒間に新生骨の形成を認めている.

このように, 埋入された顆粒状 HAP 間隙組織には新 生骨が形成されるとの報告が多いが，その形成の速度や 様相には若干の差が認められる. それは, 実験動物の骨 膜の骨形成能や，HAP の骨膜下埋入位置などの生体側の 因子と HAP 側の因子，すなわち使用した顆粒の焼成法， 特に温度や, 粒径, 形態, 表面性状の差異などにより影 響を受けたものと推測される.しかし，いずれの報告で も, 術後まもなく顆粒状 HAP は線維性組織により被包 化されるという点では一致しており，臨床的にも早期に 周囲組織と一体化して不動性を示し，義歯の支持基盤と して機能しうることが推測される.

なお，HAP が埋入された頼堤の硬度は，サルの実験で は, 6 力月後で海綿骨よりも硬く, 緻密骨と海綿骨の中 間の値を示したとの報告がある199. 

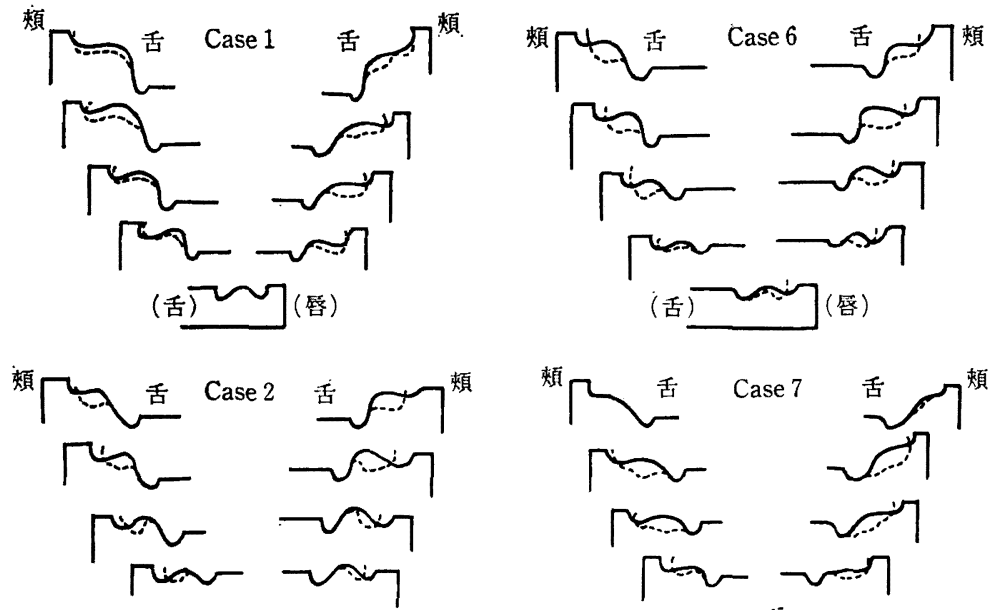

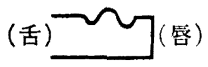

(舌) (長)
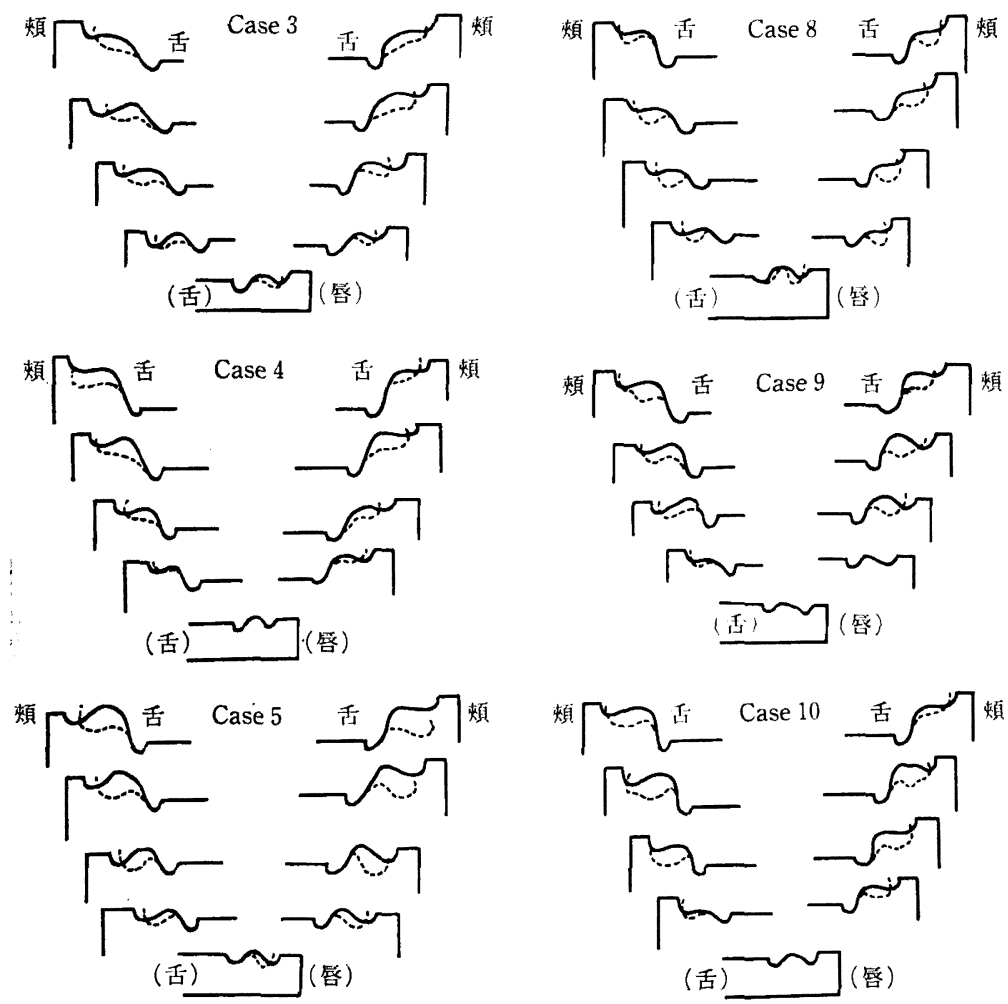

図 7 術前・後の颖堤形態の比較

2. 顎堤形成法について

顎堤形成法は，口腔前庭を拡張して䫟堤形態を改善す る相対的㱛堤形成法と, 下頭骨自体の高さを増加させよ うとする絶対的頻堤形成に分類される11. HAP を使用す
る䫑堤形成法は，後者に分類されるものであるが，これ まで本法以外にもいくつかの絶対的顎堤形成が試みられ てきた.たとえば,吸収した顎堤上に他の部位より採取し た自家骨を移植する Onlay Graft ${ }^{3 \sim 5)}$, 下頡骨体を矢状分 
割あるいは，水平分割し移動固定する Visor Osteotomy 6,7)などやそれらの改良術式である1,2). しかし，それらの 方法では患者の年龄を考慮すると，骨採取のための手術 侵襲が大きいことや，移植部位の経時的な骨吸収による

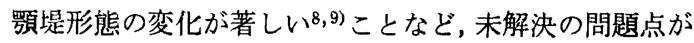
残されたため, 広く臨床応用されるには至らなかった.

顆粒状 HAP による無歯頡顎堤形成は 1980 年, Kent $ら^{10)}$ により発表されて以後, 多数の報告例がみられ, 最 近では顎堤形態の改善効果を高めるために，外科手術術 式の改良や異種材料の混入 ${ }^{39 \sim 46)}$, さらに床副子の改 良 ${ }^{47 \sim 54)}$ について述べた論文も多い.

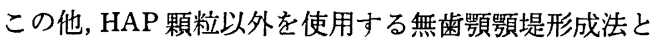
して, ブロック状の HAP を一塊として骨膜下に埋入す

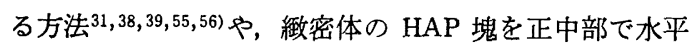

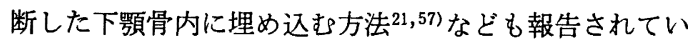
る.

さらに, 無歯頡顎堤のみならず, 特に前歯部ブリッジ のポンティック基底部萼堤形態を HAP 埋入によって改 善し, ポンティック部の審美性を向上させる方法も行わ れている88 91).

\section{3. 顎堤形態の分析結果について}

1) パノラマX線写真による計測結果

下顎骨体部の高さの増加は，必ずしも義歯の支持基盤 として機能しらる顎堤の良否を評価する基準とはいえな いが、これまでにいくつかの論文で報告されている結果 と著者らの結果とを比較するために, 同様な方法で骨体 部の高さを計測した.

著者らによる計測では下顎骨体部の高さの増加は 37 〜92\%に及び,これまでの報告11 14,36) とほぼ同様な結果 であり，著明な高さの増加が認められた。

形成部位における高さの経時的な娍少に関して,Block ら ${ }^{14)}$ は, 術直後を基準とした観察によって, 48 カ月の吸 収が平均約 4\% であったとし，また Cranin ら 371 6〜9 カ月の吸収が $10 \%$ 以下であったと報告している. 今回 の著者らの計測においては, 最長 30 力月経過 後の 2 症 例の平均で約 $10 \%$ の減少が認められ, それらの報告よ り若干大きかった. しかし，実際に義歯を製作開始する 術後 1 力月を基準とすると約 $6 \%$ の減少であり, 本法に より形成された顎堤が義歯装着後も長期にわたり, その 形態の保持が可能であることが推測された.

なお, 従来の自家骨移植による方法では, 術後の吸収 量が大きく, Baker ら ${ }^{8)}$ は術後 1〜2 年間で少なくとも 40〜60\%, 3〜 5年では 60〜 100\%, Curtis ら9 は 92 力月
で平均約 $60 \%$ にも及ぶ吸収量を報告しており，䅡堤の 長期にわたる安定性に関しても本法は優れた顎堤形成法 であるといえる。

\section{2）義歯負担域面積}

義歯床外形の設計は術者により異なり, 術前・後の負 担域面積を客観的な基淮を設けて正確に比較することは 困難である.ここでは臨床経験 10 年以上の同一術者が 同一の精密印象術式によって得られた模型により,これ を義歯負担域として面積を測定した。

顎堤形成術後の面積は術前と比較して, 全症例の平均 で約 31\% の増加を示していた．このことは，本法が義 歯の支持および維持安定の向上に大きく寄与しているこ とを示唆している. この義歯負担域面積の増加は, 術後 の䫟堤断面形態からも示されるように，舌側での顎堤の 高さの増加と, 煩側への拡大による増加が複合された結 果によりもたらされたものと理解され，本法が口腔前庭 拡張術と同様な効果を有することが示唆された. なお, 煩側の面積の増加率が少ない症例 9,10は, トンネル形 成時の煩側の骨膜剝離が不十分で, さらに術後に固定用 床副子を使用しなかったものである.このことから，骨 膜の剝離部位および量, HAP の注入部位, 床副子使用の 有無などが，煩側の義歯負担城の搪張に影響を及ぼす因 子であることが推測された。

3）䪽堤断面形態

いずれの症例においても，煩舌的な䫟堤断面形態には 著明な変化が認められた. すなわち, 舌側は㖽堤の高さ が増加して解剖学的維持力 ${ }^{92)}$ の向上に寄与していると考 えられ，一方，煩側は義歯負担域面積の計測から明らか なように，口腔前庭が拡張されることが示された. これ は, HAP 顆粒が外斜線に起始する煩筋の下部に侵入する ことによって, 煩䇗が挙上されて弛緩したためであり ${ }^{26)}$, さらに大きく義歯床縁の延長が可能となるものと推測さ れる. また, 煩側の拡大があまり認められなかった症例 9,10は, 顆粒の煩側への migration を回避するため, 㛲 側骨膜の剝離を意識的に小範囲にとどめたものである が, この顎堤形態の分析から, 義歯負担域の拡大にとっ ては,むしろ少量の顆粒が煩側に埋入されることが必要 と考えられる.

Moses $^{93)}$ は, 顎堤頂が幅広く, 煩舌側ともに高い顎堤 形態を最も良好な義歯支持基盤であるとしているが，本 法によって形成された顎堤は, 舌側では高さが獲得され るものの, 煩側については高さよりも広さが獲得され比 較的平坦な形態となった. しかし, 煩側に認められる口 腔前庭拡張の効果は煩棚付近で著明であり，この形態は 


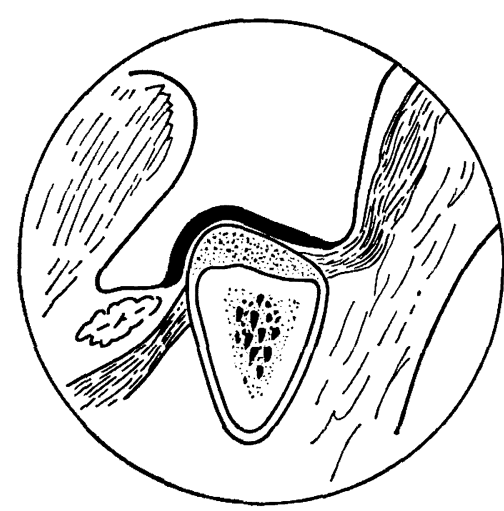

図 8 本顎堤形成法によって獾得されるべき 望ましい顎堤形態（太線部）

義歯の支持および維持安定の観点からも有利であると考 えられる.

これらのことから，本法によって獲得される良好な顎 堤とは図 8 に示す形態であり，術前のワックスでの予測 模型はこのような形態に設計すべきであると考える.

症例 7 の左側臼歯部では煩側のみが過度に挙上され， 䫘堤は煩側から舌側に傾斜する単斜面を形成しており, 義歯の支持基盤として不適当な形態となった (図 9). こ れは手術時にトンネル形成が煩側に向かったため HAP 顆粒が煩側寄りに埋入されたことと，固定用として骨膜 下に残した床副子の位置が舌圧などにより煩側に移動し てしまったためと推測される.このことから，煩側への 過度の埋入や migration は回避すべきであり，外科手術 時のトンネル形成と,ガイド固定兼用床副子の使用には 十分な注意が必要と考えられた.

\section{4. 床副子の有効性について}

術後の固定用の床副子に関しては，その効果を疑問視 する報告もみられる26). しかし，本研究においては，適 切な固定用床副子を下顎骨に囲繞結栵することにより， 䫟堤面積の増加率が大きく(症例 $2,3,5,6)$, 形態的にも 望ましい顎堤が得られたと判断された. さらに，装着後 の経過観察においても，床副子使用例と非使用例との間 には明らかな差が認められ，前者（症例 1～6）では咬合 調整と粘膜面の適合調整に要した回数は少なく，長期的 にみてもリライニングなどの大幅な改善は必要とされな かった. これに対し, 後者（症例 8～10）では術後の頡 堤の変化が大きいため, しばしば粘膜の疼痛や義歯の維 持力不足がおこり，義歯の調整回数も多く，いずれも 6 カ月以内にリライニングが必要となった.

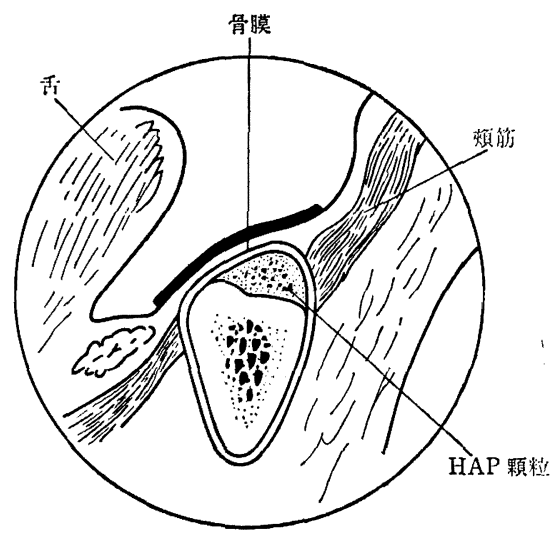

図 9 煩側が過度に挙上され，義歯の支持基盤 としては望ましくない䫟堤形態(太線部)

床副子の有用性については, 近年, 床副子の設計に関 する論文47 54) が多く発表されていることからも明らか であり, 埋入された顆粒が線維性組織に被包されて安定 するまでの期間, 形態保持のために㨽子の使用が必要 と考えられる.

すなわち，術直後の床副子の使用は本法においては必 須のむのと考えられるが，付与すべき床副子の形態に関 しては,さきに考察したように補綴学的見地からの慎重 な検討が必要であると思われた。

\section{5. 補綴処置との関連について}

1) 診查

診査に際し，患者の全身状態の把握は外科処置を行う ためにも必須なことである.さらにまた，患者の義歯に 対する理解も必要であり, 症例の選択には十分の注意が 払われるべきである.

補綴学的見地からの診査において, 義歯支持基盤とし て望ましい頡堤形態を, 対向関係とともに十分検討する ことが重要と考えられる.すなわち, HAP 埋入部位およ び形態の決定に関しては，上下頡の垂直的および水平的 位置関係をも十分に診査すべきであり，咬合平面や歯槽 頂間線，顎堤間距離，顎堤の対向関係など義歯の維持安 定や審美性に関与する因子を考慮すべきである $26,29,30$, 32).

2）義歯の製作開始時期

HAP 埋入部への機能圧付加の開始時期に関していく つかの報告がある.

Chang ら ${ }^{78)}$ は，骨膜下に埋入された顆粒状 HAPに対 する組織反応所見から，新義歯の製作開始，すなわち印 象採得汁外科手術後 1 力月以降とすることを推奨してお 
り，さらに術後 $3 \sim 6$ カ月までは粘膜に加わる咬合力を 制限し, 機能的な咬合力負担は 6 力月以降にすべきであ

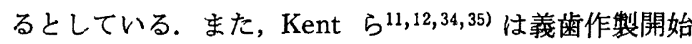
を，顆粒状 HAP のみを用いた額堤形成の場合 $2 \sim 3$ 週 後, 海綿骨逞と混合して用いた場合 4 6 週後と 述 べ, 骨のアンダーカット部のみを形成するような部分的手術 ではさらに早期に義歯を作製できると報告している. Larsen $ら^{13)}$ は義歯装着時期を, 部分的手術では 4 6 週 後, 㴿堤全体に及ぶ場合は 8 12 週後と報告しており, また Block ら ${ }^{14)}$ も 74 症例で平均 2.1 力月後には義歯を 装着し，その後の影堤にはほとんど変化を認めなかった と報告している.

著者らも，術後 4 週目以降を新義歯の製作開始時期と した. この時期には，触診による滪堤の固さが通常とほ ぼ同程度までに回復しており, 義歯装着後の粘膜や䫟堤 にも顎堤形成に起因すると思われる障害は認められなか った．またX線観察による外科手術 1 力月以降の吸収変 化も僅少であったことから，この製作開始時期は適切な ものであると考えられた。

3）義歯の製作・装着に関しての術式

印象採得：本法では顎堤形態および面積の分析によ。 ても明らかなように，煩側部での拡張が認められてお り,この部の印象採得が義歯の支持・維持にとって重要 であると考える。

咬合採得：頡堤形成が施された場合，上下䫟間距離が 減少し, 上下歯槽頂の前後的平行関係も変化しているた め, 顎堤間の平均的計測值を利用する咬合採得法 ${ }^{92}$ は, 不適当な咬合高径や誤った咬合平面を設定する危険性が 生じやすい，なお， 目後パッドは術後も位置的変化が少 ないため，咬合採得の基準点として有効であると考えら れる.

人工歯の選択, 排列 : 義菌により预堤に加えられる機 械的刺激は可及的に小さいことが望ましく, 人工歯の選 択と排列および咬合様式などに関しては考慮すべきであ る. 著者らは, 人工歯はレジン歯を選択し、ニュートラ ルゾーン94)を参考に排列位置を決定した. また，ワイド

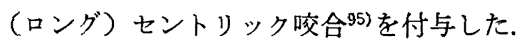

義歯の装着と調整 : 新義歯の装着は, まだ組織の安静 が要求される時期に行われることになる.したがって, 十分な咬合調整と粘膜面適合検查を行い, 義歯による粘 膜および HAP 一の過度の機械的刺激を避ける必要があ る. 特に, 術後の㯋堤粘膜には感覚閾の上昇が認められ ているため ${ }^{96)}$, 定期的なリコールを行い, 調整, 観察を 続ける必要があると考光られる。

\section{VI. 結 論}

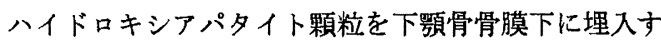
る無歯題䪽堤形成法を施行した 10 症例について, 術後 最長 30 力月にわたる経過観察と䫑堤形態の分析を行っ た. その結果,

1. 外科手術による重篤な偶発症は認められなかっ た.

2. 装着された全部床義歯の経過は手術術式と固定用 林副子の使用の有無によって差が認められ，固定用床副 子を使用した症例では，その経過はとくに良好であっ た.

3. パノラマX線による下頡骨体の観察では, 術後に 高さは平均約 $59 \%$ の増加が認められ, 1 力月以後の経時 的な減少も最長 30 カ月で約 $6 \%$ であった.

4. 術後の義歯負担域面積は, 平均約 $32 \%$ の增加が 認められた. また, 固定用床副子の使用症例では非使用 症例に比べ面積の増加が大きかった。

5. 術後の頻堤の煩舌的断面形態は, 舌側では高く, 煩側では広く平坦に形成されていることが観察され，義 歯の維持および支持に有利であることが示唆された.

以上のことから，十分な補緅学的検討を行ったうえ で, 固定用床副子を併用する HAP 顎堤形成法が，全部 床義歯の良好な支持基盤を確保するために有効であるこ とが明らかとなった。

\section{文献}

1）金沢正昭：萎縮䪽堤に対する補綴前外科手術, 東日本歯誌, $1: 19 \sim 38,1982$.

2) Sickels, J.E. and Montgomery, M.T. : Review of surgical ridge augmentation procedures for the atrophied mandible, J Prosthet Dent, $51: 5 \sim 10,1984$.

3) Davis, W.H., Delo, R.I., Weiner, J.R. and Terry, R. : Transitional bone graft for atrophy of the mandible, $\mathrm{J}$ Oral Surg, $28: 760 \sim 765,1970$.

4) Curtis, T.A. and Ware, W.H. : Autogeneous bone graft procedures for atrophic edentulous mandibles, J Prosthet Dent, $38: 366 \sim 379,1977$.

5) Wang, J.H., Waite, D.E. and Steinhauser, E. : Ridge augmentation: An evaluation and follow-up report, J Oral Surg, $34: 600 \sim 602,1976$.

6) Härle, F.: Visor osteotomy to increase the absolute height of the atrophic mandible. A preliminary report, 
J Oral Maxillofac Surg, $3: 257 \sim 260,1975$.

7) Peterson, L.J. and Slade, E.W. : Mandibular ridge augmentation by a modified visor osteotory : Preliminary report, J Oral Surg, 35 : 999 1004, 1977.

8) Baker, R.D., Terry, B.C., et al. : Longterm results of alveolar ridge augmentation, J Oral Surg, $37: 486 \sim 489$, 1979.

9) Curtis, T.A., Ware, W.H., Beirne, O.R. and Frankel, M.E. : Autogenous bone grafts for atrophic edentulous mandibles: A final report, J Prosthet Dent, $57: 73 \sim 77$, 1987.

10) Kent, J.N., James, R., Finger, I., et al. : Augmentation of deficient edentulous alveolar ridges with dense polycrystalline hydroxylapatite, $8 \sim 12$, First World Biomaterials Congress, Baden, 1980.

11) Kent, J.N., Quinn, J.H., Zide, M.F., et al. : Correction of deficient alveolar ridge with nonresorbable hydroxylapatite alone or with autogenous cancellous bone, J Am Dent Assoc, 105 : 993 1001, 1982.

12) Kent, J.N., Quinn, J.H., Zide, M.F., et al. : Alveolar ridge augmentation using nonresorbable hydroxylapatite with or without autogenous cancellous bone, J Oral Maxillofac Surg, $41: 629 \sim 642,1983$.

13) Larsen, H.D., Finger, I.M., et al. : Prosthodontic management of the hydroxylapatite denture patient: A preliminary report, J Prosthet Dent, $49: 461 \sim 470,1983$.

14) Block, M.S. and Kent, J. N. : Long-term radiographic evaluation of hydroxylapatite-augmented mandibular alveolar ridges, J Oral Maxillofac Surg, $42: 793 \sim 796$, 1984.

15) Alling, C.C. : Hydroxyapatite augmentation of edentulous ridges, J Prosthet Dent, $52: 828 \sim 831,1984$.

16) Rothstein, S.S., Paris, D.A. and Zacek, M.P. : Use of Hydroxylapatite for the augmentation of Deficient AIveolar Ridges, J Oral Maxillofac Surg, $44: 224 \sim 230$, 1984.

17) Rothstein, S.S., Paris, D.A. and Sage, B. : Use of Durapatite for the rehabilitation of resorbed Alveolar Ridges, J Am Dent Assoc, 109 : 571 574, 1984.

18) Waite, D.E. : Alveolar ridge augmentation and the edentulous patient - Current clinical consideration, New Dimentional Oral Surg, 1:2 13, 1984.

19）柳沢定勝, 吉峰一夫, 高田尚美, 小澤俊文, 他: 合成七ド ロキシアパタイトによる歯槽堤造成法 1. 基礎的背景(上) (下), 日本歯科評論, $502: 99 \sim 109,503: 83 \sim 94,1984$.

20）柳沢定勝, 吉峰一夫, 高橋英司, 高田尚美, 他 : 合成七ド ロキシアパタイトによる歯槽堤造成法 2. 臨床応用 (上) (下), 日本歯科評論, $504: 69 \sim 79,505: 74 \sim 89,1984$.
21）倉科㶳治, 矢島幹人, 武田 進, 山崎 正, 䋃村俊一, 他 : Ceramic 材料の臨休态用に関する研究 第 $\mathbf{5}$ 報 口腔外科 領域での hydroxyapatite ceramics の使用経験, 日口外誌, $31: 2169 \sim 2178,1985$.

22）久野吉雄, 宮下幸久, 野村 篤, 道健一, 長谷川幸司, 他：ハイドロキシアパタイト（calcitite）の臨床使用経験， 日口外誌, $31: 1602 \sim 1611,1985$.

23) Mercier, P. : Ridge form in preprosthetic surgery, Oral Surg Oral Med Oral Pathol, 60 :235 243, 1985.

24) Griffiths, G.R. : New hydroxyapatite ceramic materials : Potential use for bone induction and alveolar ridge augmentation, J Prosthet Dent, 53 (1) : 109 114, 1985.

25) Beirne, O.R. and Curtis, T.A. : Patient satisfuction with dentures following alveolar ridge augmentation with hydroxyapatite, Can Dent Assoc, $13: 45,1985$.

26) Desjardins, R.P. : Hydroxyapatite for alveolar ridge augmentation: Indications and problems, $\mathrm{J}$ Prosthet Dent, $54: 374 \sim 383,1985$.

27) White, E. and Short, E.C. : Biomaterial Aspects Of Interpore-200 Porous Hydroxyapatite, Dent Clin North Am, $30: 49 \sim 67,1986$.

28）田中 收, 村瀬博文, 永井教之: 顆粒状ハイドロキシアパ タイトによる無歯顎頻堤形成法と補緅処置 (上) 文献の展 望による評価, 歯界展望, 68 (3)：601 615，1986.

29）田中收, 村瀨博文, 他: 顆粒状ハイドロキシアパタイト による無菻額䪽堤形成法と補緅処置（下）臨床例による評 価, 歯界展望, 68 (4) : 827 839, 1986.

30）田中 收, 村瀬博女: 合成ハイドロキシアパタイト顆粒を 用いた無蒾顎額堤形成法, 東日本デンタルトピックス, 1 : $5 \sim 12,1986$.

31）村瀬博文, 平 博彦, 麻生智義, 田中 收, 他：ハイド口

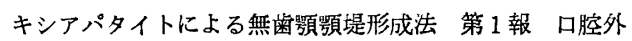
科的アプローチ, 北海道歯科 医 師 会誌, $42: 153 \sim 159$, 1987.

32）田中收, 越智守生, 白井伸一, 紀田樹介, 他：ハイド口 キシアパタイトによる無歯影影堤形成法 第 2 報 補緅学 的アプローチ, 北海道歯科医師会, $42: 160 \sim 167,1987$.

33）村瀬博文, 平 博彦, 麻生智義, 北村完二, 田中 收, 他: 補緅前処直としてのハイドロキシアパタイトによる無歯頡 顎堤形成法, 日口外誌, 33 (12) : 2408 2418, 1987.

34) Kent, J.N. : Reconstruction of the Alveolar Ridge with Hydroxyapatite, Dent Clin North Am, 30 (2) : 231 257, 1986.

35) Kent, J.N., Finger, I.M., Quinn, J.H. and Guerra, L. R. : Hydroxylapatite alveolar ridge reconstruction, J Oral Maxillofac Surg, $44: 37 \sim 49,1986$.

36) 高橋庄二郎, 斎藤 力, 大畠 仁, 園山 䄯, 高森 等, 他：口腔外科領域におけるハイドロキシアパタイト・セラ 